\title{
PENGARUH STRESS KERJA DAN MOTIVASI KERJA TERHADAP PRESTASI KERJA KARYAWAN PADA PT. FRISIAN FLAG INDONESIA WILAYAH PADANG
}

\author{
Yanne Aldi, Febsri Susanti \\ Sekolah Tinggi Ilmu Eknomi "KBP" \\ febsrisusanti@akbpstie.ac.id
}

\begin{abstract}
ABSTRAK
Tujuan dari penelitian ini adalah untuk mengetahui dan menganalisis pengaruh stress kerja dan motivasi kerja terhadap prestasi kerja karyawan pada PT. Frisian Flag Indonesia Wilayah Padang. Teknik sampling yang digunakan adalah tottal sampling, sedangkan jumlah sampel yang digunakan untuk analisis adalah 36 orang. Teknik analisis data yang digunakan untuk menguji hipotesis adalah regresi linier berganda. Dalam penelitian ini terdapat dua variabel bebas, yaitu stress kerja dan motivasi kerja. Variabel stress kerja dan motivasi kerja tidak memiliki pengaruh terhadap prestasi kerja karyawan pada PT. Frisian Flag Indonesia Wilayah Padang. Sedangkan nilai koefisien determinasi dalam penelitian ini ditemukan sebesar 0,014 atau sama dengan 1,4\%. Hasil tersebut memperlihatkan bahwa dari prestasi kerja karyawan yang dapat dijelaskan oleh stress kerja dan motivasi keerja sebesar 1,4\%, sedangkan sisanya $98,6 \%$ diduga dijelaskan oleh faktor-faktor lain yang tidak diteliti dalam penelitian ini, seperti disiplin kerja, budaya organisasi, iklim kerja, kepemimpinan, kompensasi, dan lingkungan kerja. Berdasarkan hasil pengujian analisis regresi linier berganda, ditemukan bahwa variabel stress kerja berpengaruh negatif terhadap prestasi kerja, sedangkan motivasi kerja berpengaruh positif terhadap prestasi kerja karyawan pada PT. Frisian Flag Indonesia Wilayah Padang. Penelitian ini memberikan rekomendasi praktis untuk manajemen PT. Frisian Flag Indonesia wilayah Padang untuk terus berupaya meningkatkan prestasi kerja di masa yang akan datang.
\end{abstract}

Kata Kunci : Stress Kerja, Motivasi Kerja dan Prestasi Kerja

\section{PENDAHULUAN}

Setiap perusahaan pasti menginginkan pegawainya mempunyai prestasi karena dengan memiliki pegawai yang berprestasi dapat meningkatkan kinerjanya. Jika penilaian prestasi kerja sangat diperhatikan maka akan menjadi fokus bagi pegawai serta untuk melihat sejauh mana tingkat keberhasilan yang bisa dicapai dalam bekerja. Sumber daya manusia merupakan salah satu faktor penting, oleh karena itu diperlukan usaha-usaha yang lebih baik dalam upaya membina manusia sebagai tenaga kerja. Tercapainya tujuan suatu organisasi tidak hanya tergantung pada peralatan modern, sarana dan prasarana yang lengkap, tetapi justru lebih tergantung pada manusia yang melaksanakan pekerjaan tersebut. Karyawan yang berkualitas adalah karyawan yang melaksanakan pekerjaannya dan mampu memberikan hasil kerja yang baik atau mempunyai prestasi kerja yang tinggi yang dibutuhkan oleh organisasi untuk mencapai tujuannya.

Untuk mencapai prestasi kerja yang baik, unsur yang paling dominan adalah sumber daya manusia, walaupun perencanaan telah tersusun dengan baik dan rapi tetapi apabila orang atau personil yang melaksanakan tidak berkualitas dan tidak memiliki semangat kerja yang tinggi, maka perencanaan yang telah disusun tersebut akan sia-sia. Prestasi kerja yang dicapai pegawai merupakan suatu hal yang sangat penting dalam menjamin kelangsungan hidup organisasi. Prestasi kerja karyawan dipengaruhi oleh bermacam-macam ciri pribadi dari masing- masing individu. Dalam perkembangan kompetitif dan mengglobal, perusahaan 
membutuhkan karyawan yang berprestasi tinggi. Pada saat yang sama, pekerja memerlukan umpan balik atas kinerja mereka sebagai pedoman bagi tindakan-tindakan mereka pada masa yang akan datang.

Menurut Hasibuan (2013:93), prestasi kerja adalah hasil kerja yang dicapai oleh seseorang dalam melaksanakan tugas-tugas yang dibebankan kepadanya yang didasarkan atas kecakapan, pengalaman, dan kesungguhan serta waktu. Adapun faktor-faktor yang mempengaruhi prestasi kerja menurut Martoyo (2007:141), adalah motivasi, kepuasan kerja, tingkat stress, kondisi fisik pekerjaan, kompensasi, aspek-aspek ekonomi, aspek-aspek teknis dan prilaku-perilaku lainnya.

Stres yang sering dialami oleh karyawan akibat lingkungan yang di sekitar tempat bekerjaakan mempengaruhi prestasi kerjanya, sehingga organisasi atau perusahaan perlu untuk meningkatkan atau mengkaji mutu organisasional bagi para pegawai. Menurunnya stres yang dialami pegawai pasti akan meningkatkan kesehatan atau mutu di dalam organisasi. Stres kerja dapat berakibat positif (eustress) yang dibutuhkan guna menghasilkan prestasi yang tinggi, namun seringkali stres kerja lebih banyak merugikan pegawai ataupun perusahaan (Munandar, 2008: 374). Dampak negatif (Distress) yang diakibatkan oleh stres kerja dapat berupa gejala fisik, maupun psikis. Gejala fisiologis mengacu pada perubahan metabolisme, meningkatnya tekanan darah, penyebab serangan jantung, dan sering timbulnya sakit kepala, sedangkan untuk gejala psikologis bisa berupa cemas, depresi, gelisah, gugup, dan agresif terhadap orang lain.

Prestasi karyawan tidak cukup hanya dengan stress kerja dari karyawan itu sendiri, tetapi bisa juga dilakukan melalui peningkatan motivasi kerja. Motivasi kerja adalah hal yang menyebabkan, menyalurkan, dan mendukung perilaku manusia, supaya mau bekerja giat dan antusias mencapai hasil kerja yang optimal (Hasibuan 2013). Disamping itu usaha untuk memacu prestasi kerja pegawai, pimpinan harus berusaha menyadari hakikat dari pekerjaan karyawan. Sehingga dapat ditentukan bentuk motivasi apa yang akan diberikan sesuai dengan kondisi kerja perusahaan.

Demikian juga halnya dengan PT. Frisian Flag Indonesia wilayah Padang yang merupakan salah satu perusahaan industri susu di Indonesia yang bisnisnya bergerak di bidang produksi dan mendistribusikan produk-produk Frisian Flag menyadari benar pentingnya memiliki karyawan yang berprestasi, yang memiliki kemampuan dan keunggulan untuk bersaing di era globalisasi. Upaya untuk meningkatkan prestasi kerja harus diimbangi oleh adanya stress kerja dan motivasi kerja karyawan. Berdasarkan penelitian awal yang peneliti lakukan, perusahaan ini menghadapi masalah mengenai tidak dapat tercapainya standar prestasi kerja karyawan dalam catur wulan pertama tahun 2017 yang ditetapkan di PT. Frisian Flag Indonesia wilayah Padang. Berdasarkan hasil observasi awal mengenai prestasi kerja karyawan pada 5 orang karyawan dari beberapa unit kerja diketahui bahwa pencapaian prestasi kerja karyawan PT. Frisian Flag Indonesia wilayah Padang masih dalam kategori belum mencapai standar.

Berkaitan dengan hal tersebut, hal ini diduga dipengaruhi oleh stress kerja pada karyawan. Setiap pekerja pasti mempunyai tingkat stress yang berbeda satu sama lain, begitu pula dengan pekerjaan yang dilakukan oleh karyawan di PT. Frisian Flag Indonesia wilayah Padang. Para karyawan adalah alat penggerak produksi yang ada di perusahaan. Maka dari itu para karyawan harus bekerja sangat keras supaya produksi tidak terhambat atau terhenti dan dapat berproduksi secara optimal.

Stress juga dapat terjadi apabila pada kondisi tersebut terjadi perbedaan aspirasi antara pegawai, disisi lain pihak permasalahan perusahaan harus segera diselesaikan karena menyangkut keberlangsungan operasional perusahaan. Terlebih, risiko pekerjaan para pegawai sangat tinggi dan rentan terjadi kecelakaan dalam proses produksi sehingga sedikit banyak akan menimbulkan stress pada karyawan yang bekerja di bagian pabrikasi. Pada akhirnya tingkat stress ini akan 
berpengaruh pada menurunnya prestasi kerja pegawai tersebut.

Dalam hal ini peneliti memfokuskan untuk melihat dampak negatif dari stress, dan bisa dilihat dari berbagai macam persoalan yang ada di kantor PT. Frisian Flag Indonesia wilayah Padang. Pegawai kantor masih sering mengerjakan tugas yang sebenarnya tidak tercantum di dalam tugas, pokok dan fungsinya. Hal itu disebabkan karena pegawai lainnya tidak memiliki cukup keahlian untuk menyelesaikannya dan kurangnya rasa tanggungjawab terhadap tugas yang diberikan kepadanya serta sifat ketergantungan masih sangat terlihat.Tidak hanya itu terkadang di kantor sering terjadi kesalahpahaman antar pegawai dan hal ini menyebabkan suasana tidak nyaman sehingga antar pegawai tidak saling tegur dan akhirnya kerjasama berkurang. Ketika ketidaknyamanan ini terjadi maka bisa memunculkan dampak negatif bagi seseorang, yang mana bisa membuat perasaan tertekan dan kondisi ketegangan yang berpengaruh terhadap emosi, jalan pikiran dan kondisi fisik seseorang. Dari fakta diatas maka dapat memicu terjadinya stress kerja terhadap pegawai. Diharapakan perusahaan mampu menangani penyebabpenyebab stress agar pekerjaan yang efektif dan efisien bisa tercapai dan tujuan organisasi tercapai serta prestasi kerja pegawaipun akan meningkat.

Selain stress kerja, faktor lain yang diduga mempengaruhi prestasi kerja yang dihadapi oleh perusahaan dewasa ini adalah kurangnya motivasi kerja pada karyawan, demikian juga dengan yang bekerja di PT. Frisian Flag Indonesia wilayah Padang. Berdasarkan pengamatan di lapangan sebagian besar karyawan terlihat kurang bersemangat dalam menyelesaikan pekerjaan yang telah ditetapkan oleh perusahaan. Kurangnya penghargaan yang diberikan oleh perusahaan seperti jarangnya para karyawan diberikan penghargaan jika mereka melakukan pekerjaan dengan baik. Disamping itu tidak adanya dorongan dari pimpinan untuk meningkatkan motivasi kerja disinyalir juga mempengaruhi terhadap prestasi kerja karyawan. Serta adanya ketidakseragaman pemberian motivasi oleh atasan terhadap setiap pegawainya.

Hal ini berakibat pada rendahnya prestasi kerja karyawan di dalam perusahaan PT. Frisian Flag Indonesia wilayah Padang. Pemberian motivasi menjadi landasan yang tepat dapat menimbulkan rasa disiplin terhadap pekerjaan. Motivasi yang diberikan oleh perusahaan merupakan salah satu cara untuk mempengaruhi bawahannya dalam meningkatkan kualitas kerjanya sehingga tujuan tercapai dan meningkatnya prestasi kerja. Ketidaksesuaian prestasi kerja karyawan dengan standar perusahaan tersebut diduga karena tingkat motivasi kerja masih rendah.

Rumusan masalah dalam penelitian ini adalah : 1) Apakah stress kerja berpengaruh terhadap prestasi kerja karyawan pada PT. Frisian Flag Indonesia Wilayah Padang. 2) Apakah motivasi kerja berpengaruh terhadap prestasi kerja karyawan pada PT. Frisian Flag Indonesia Wilayah Padang.

\section{LANDASAN TEORI}

Manajemen Sumber Daya Manusia atau yang sering dikenal dengan Human Resource Management merupakan aset kritis organisasi yang tidak hanya diikutsertakan dalam filosofi perusahaan tetapi juga dalam proses perencanaan strategis. Sumber daya manusia memiliki posisi yang sangat strategis dalam organisasi, artinya unsur manusia memegang peranan penting dalam melakukan aktivitas untuk mencapai tujuan. Eksistensi sumber daya manusia itulah yang terdapat dalam organisasi yang kuat. Mencapai kondisi yang diharapkan diperlukan adanya manajemen terhadap sumber daya manusia secara memadai sehingga terciptalah sumber daya manusia yang berkualitas, loyal dan berprestasi.

Menurut Mathis dan Jackson (2012:5), manajemen sumber daya manusia dapat diartikan sebagai ilmu dan seni yang mengatur hubungan dan peranan tenaga kerja agar efektif dan efisien dalam penggunaan kemampuan manusia agar dapat mencapai tujuan di setiap perusahaan. Sedangkan menurut Mangkunegara (2013:2) mengatakan bahwa "Manajemen 
sumber daya manusia merupakan suatu perencanaan, pengorganisasian, pengkoordinasian, pelaksanaan, dan pengawasan terhadap pengadaan, pengembangan, pemberian balas jasa, pengintegrasian, pemeliharaan, dan pemisahan tenaga kerja dalam rangka mencapai tujuan organisasi."

Prestasi kerja disebut juga sebagai kinerja atau performance. Pada prinsipnya, ada istilah lain yang lebih menggambarkan pada "prestasi" yaitu kata "achievement". Tetapi karena kata tersebut berasal dari kata "to achieve" yang berarti "mencapai", maka dalam bahasa Indonesia sering diartikan menjadi "pencapaian" atau "apa yang dicapai".

Prestasi kerja adalah hasil upaya seseorang yang ditentukan oleh kemampuan karakteristik pribadinya serta persepsi terhadap perannya terhadap pekerjaan itu (Sutrisno, 2011:149). Menurut Mangkunegara (2013) prestasi kerja adalah hasil kerja secara kualitas dan kuantitas yang dicapai oleh seorang pegawai dalam melaksanakan tugasnya sesuai dengan tanggung jawab yang diberikannya. Prestasi kerja adalah suatu hasil kerja yang dicapai seseorang dengan melaksanakan tugas yang dibebankan kepadanya yang didasarkan atas kecakapan, pengalaman, kesungguhan serta waktu (Hasibuan 2013).

Prestasi kerja seseorang ditunjukkan dengan keseriusanya dalam menyelesaikan tugas-tugas yang dibebankan kepadanya berdasarkan atas kecakapan, pengalaman, kesungguhan serta waktu (Hasibuan, 2013). Selanjutnya juga dikatakan bahwa hasil kerja atau prestasi merupakan gabungan dari tiga faktor yaitu (a) minat dalam bekerja, (b) penerimaan delegasi tugas, dan (c) peran dan tingkat motivasi seorang pegawai.

Menurut Sunyoto (2015:216) stress adalah konsekuensi setiap tindakan dan situasi lingkungan yang menimbulkan tuntutan psikologis dan fisik yang berlebihan pada seseorang. Selanjutnya, stres kerja adalah sesuatu kondisi ketegangan yang menciptakan adanya ketidakseimbangan fisik dan psikis, yang mempengaruhi emosi, proses berpikir, dan kondisi seorang karyawan (Rivai 2004:108).
Menurut Robbins (2008:368) stres adalah suatu kondisi dinamis di mana seorang individu dihadapkan pada peluang, tuntutan, atau sumber daya yang terkait dengan apa yang dihasratkan oleh individu itu dan hasilnya dipandang tidak pasti dan penting.

Mangkunegara

(2008:179)

mengemukakan stres kerja sebagai suatu ketegangan atau tekanan yang dialami ketika tuntutan yang dihadapkan melebihi kekuatan yang ada pada diri kita. Sedangkan Handoko (2001:63) menyebutkan bahwa stres adalah tuntutan-tuntutan eksternal yang mengenai seseorang, misalnya obyek-obyek dalam lingkungan atau suatu stimulus yang secara obyektif adalah berbahaya. Stres juga biasa diartikan sebagai tekanan, ketegangan atau gangguan yang tidak menyenangkan yang berasal dari luar diri seseorang. Begitu pula menurut Hasibuan (2009) mengemukakan bahwa stres adalah suatu kondisi ketegangan yang mempe-ngaruhi emosi, proses berfikir dan kondisi seseorang.

Menurut Kadarisman (2013:275) motivasi diartikan sebagai keseluruhan proses pemberian dorongan atau rangsangan kepada para karyawan sehingga mereka bersedia bekerja dengan rela tanpa dipaksa. Organisasi akan berhasil melaksanakan programprogramnya bila orang-orang yang bekerja dalam organisasi dapat melaksanakan tugasnya dengan baik sesuai dengan bidang dan tanggung jawabnya masing-masing. Dalam melaksanakan tugas tersebut, para pegawai perlu diberikan arahan dan dorongan sehingga potensi yang ada dalam dirinya dapat diubah menjadi prestasi yang menguntungkan organisasi.

Menurut Rivai (2005) dalam Kadarisman (2013:276) motivasi adalah serang-kaian sikap dan nilai-nilai yang memengaruhi individuuntuk mencapai hal yang spesifik sesuai dengan tujuan individu. Sikap dan nilaitersebut merupakan suatu yang invisible yang memberikan kekuatan untukmendorong individu untuk bertingkah laku dalam mencapai tujuan.Sedangkan menurut Robbins (1982) dalam Kadarsiman (2013:274) mengemukakan 
bahwa motivasi kerja merupakan keinginan untuk melakukan sebagai kesediaan untuk mengeluarkan tingkat upaya yang tinggi untuk tujuantujuan organisasi, yang dikondisikan oleh kemampuan upaya itu untuk memenuhi suatu kebutuhan individual.

Menurut Sunyoto (2015:216) stress adalah konsekuensi setiap tindakan dan situasi lingkungan yang menimbulkan tuntutan psikologis dan fisik yang berlebihan pada seseorang. Selanjutnya, stres kerja adalah sesuatu kondisi ketegangan yang menciptakan adanya ketidakseimbangan fisik dan psikis, yang mempengaruhi emosi, proses berpikir, dan kondisi seorang karyawan (Rivai 2004:108).

Dari uraian diatas dapat disimpulkan bahwa terjadinya stress kerja adalah dikarenakan adanya ketidakseimbangan antara karakteristik kepribadian karyawan dengan karakateristik aspek-aspek pekerjaannya dan dapat terjadi pada semua kondisi pekerjaan. Adanya beberapa atribut tertentu dapat mempengaruhi daya tahan stress seorang karyawan.

Penelitian yang dilakukan oleh Anisah Nurmalasari. (2015) dengan judul Pengaruh Stress Kerja Terhadap Prestasi Kerja Pegawai Di Kecamatan Malinau Kota Kabupaten Malinau.. Adapun temuan dalam penelitian ini adalah pertama, stress kerja ternyata mempunyai pengaruh terhadap prestasi kerja pegawai pada kecamatan malinau kota kabupaten malinau. Kedua, besarnya pengaruh stress kerja terhadap prestasi kerja di Kecamatan Malinau Kota Kabupaten Malinau adalah sebesar 39,80\%.

Penelitian lain yang dilakukan oleh Endang Suswati dan Ibnu Azizi Al Ayyubi (2008) dengan judul Pengaruh Stress Kerja Terhadap Prestasi Kerja Karyawan.. Dimana terdapat pengaruh yang signifikan secara simultan dari stress kerja yang meliputi stress fisiologis, stress psikologis dan stress perilaku terhadap prestasi kerja karyawan bagian produksi pada perusahaan pengalengan ikan PT. IndohamaFish Bali.

Penelitian yang dilakukan oleh Inke Okta Putri Wulandari, dkk. (2015) dengan judul penelitian Pengaruh Stres Kerja Dan Lingkungan Kerja Terhadap Prestasi Kerja (Studi Pada Karyawan Bagian Pabrikasi Pg. Kebon Agung Malang).Hasil $t$ test antara variabel stress kerja dengan variabel prestasi kerja berpengaruh signifikan, yang berarti prestasi kerja dapat dipengaruhi oleh stress kerja.

Penelitian Nurlia Karim. (2013) dengan judul penelitian Stres Kerja Pengaruhnya Terhadap Prestasi Kerja Pada Karyawan Café Bambu Express Manado.Hasil penelitian secara simultan faktor-faktor stress kerja seperti konflik kerja, beban kerja, waktu kerja dan kepemimpinan secara bersama berpengaruh terhadap prestasi kerja karyawan Cafe Bambu Ekspress Manado.

Menurut Kadarisman (2013:275) motivasi diartikan sebagai keseluruhan proses pemberian dorongan atau rangsangan kepada para karyawan sehingga mereka bersedia bekerja dengan rela tanpa dipaksa. Organisasi akan berhasil melaksanakan programprogramnya bila orang-orang yang bekerja dalam organisasi dapat melaksanakan tugasnya dengan baik sesuai dengan bidang dan tanggung jawabnya masing-masing. Dalam melaksanakan tugas tersebut, para pegawai perlu diberikan arahan dan dorongan sehingga potensi yang ada dalam dirinya dapat diubah menjadi prestasi yang menguntungkan organisasi.

Menurut Sunyoto (2015:199), tujuan pemberian motivasi antara lain mendorong gairah dan semangat kerja karyawan, meningkatkan moral dan kepuasan kerja karyawan, meningkatkan produktifitas kerja karyawan, mempertahankan loyalitas dan kestabilan karyawan perusahaan, meningkatkan kedisiplinan dan menurunkan tingkat absensi karyawan, menciptakan suasana dan hubungan kerja yang baik, meningkatkan dan partisipasi karyawan, meningkatkan kesejahteraan karyawan, mempertinggi rasa tanggug jawab karyawan terhadap tugas-tugasnya.

Penelitian yang dilakukan oleh Achmad Rusyad Manfaluti, dkk. (2016) dengan judul penelitian Pengaruh Motivasi Dan Kompensasi 
Terhadap Prestasi Kerja Karyawan Perusahaan Daerah Air Minum Kota Mojokerto. Berdasarkan $t$ uji yang telah dibahas pada bagian sebelumnya jelas bahwa seluruh variabel independent yang terdiri motivasi dan kompensasi secara parsial berpengaruh signifikan terhadap prestasi kerja karyawan perusahaan daerah air minum Kota Mojokerto.I METODE PENELITIAN

Jenis penelitian ini adalah penelitian deskriptif kuantitatif.Penelitian ini disebut penelitian deskriptif karena penelitian yang dilakukan dengan tujuan utama untuk memberikan gambaran atau deskripsi tentang suatu keadaan secara objektif.Sukmadinata (2011) penelitian deskriptif adalah suatu metode yang ditujukan untuk menggambarkan fenomena-fenomena yang ada, yang berlangsung pada saat ini atau saat yang lampau.Penelitian kuantitatif merupakan data penelitian yang berbentuk angka atau data kuantitaif yang diinginkan atau scoring (Sugiyono, 2013).Penelitian deskriptif kuantitaif merupakan pengumpulan dan pengukuran data yang berbentuk deskripsi dan angka.

Penelitian ini di lakukan pada karyawan PT. Frisian Flag Indonesia Wilayah Padang. Penelitian ini akan di laksanakan pada bulan Oktober 2017 sampai dengan selesai.

Dalam suatu kegiatan baik yang bersifat ilmiah maupun yang bersifat sosial, perlu dilakukan pembatasan populasi dan cara pengambilan sampel. Sampel yang diambil unsur-unsurnya harus representatif artinya dapat mewakili keseluruhan dari populasi.Menurut Sekaran (2006:121), populasi mengacu pada keseluruhan kelompok orang, kejadian, atau hal minat yang ingin peneliti investigasi. Di dalam penelitian ini yang menjadi populasi adalah seluruh karyawan PT. Frisian Flag Indonesia Wilayah Padang yang berjumlah 36 orang.

Sampel adalah sebagian dari populasi.Sampel terdiri atas sejumlah anggota yang dipilih dari populasi (Sekaran, 2006:123).Menurut Arikunto (2010) jika jumlah populasi kurang dari seratus orang, maka seluruh populasi dijadikan sampel.Pengambilan sampel dalam penelitian ini adalah dengan teknik total sampling, yaitu metode pemilihan sampel yang diaplikasikan pada seluruh anggota populasi, populasi pada penelitian ini sebanyak 36 orang.

Instrumen adalah alat untuk mengumpulkan data yang dikembangkan dengan bantuan kajian teori, definisi operasional, variabel penyebab, dan variabel akibat yang seharusnya dikembangkan dengan penjabaran indikator-indikator.Instrumen yang digunakan adalah kuesioner, di mana responden diminta untuk memberikan tanggapan dengan menandai salah satu jawaban yang diberikan.

Kuesioner yang digunakan dalam penelitian yang akan dilakukan ini disusun dengan menggunakan skala Likert. Skala ini banyak digunakan karena skala ini memberikan peluang kepada responden untuk mengekspresikan perasaan mereka dalam bentuk persetujuan atau agreement terhadap suatu pertanyaan. Pertanyaan berjenjang, mulai dari tingkat rendah sampai tertinggi. Pilihan jawaban bisa tiga, lima, tujuh, sembilan, dan harus ganjil.

\section{HASIL PENELITIAN \\ DAN \\ PEMBAHASAN}

Uji regresi linear berganda merupakan teknik statistik yang digunakan untuk menguji pengaruh beberapa variabel bebas terhadap variabel terikat (Sekaran, 2006). Hasil analisis regresi linier berganda dapat diringkas pada Tabel berikut ini:

\section{Ringkasan Hasil Analisis Regresi Linier} Berganda

\begin{tabular}{|l|r|r|c|}
\hline $\begin{array}{c}\text { Konstanta } \\
\text { dan } \\
\text { Variabel } \\
\text { Bebas }\end{array}$ & $\begin{array}{c}\text { Koefisien } \\
\text { Regresi }\end{array}$ & $\begin{array}{c}\text { Signifika } \\
\mathrm{n}\end{array}$ & $\begin{array}{c}\text { Keterang } \\
\text { an }\end{array}$ \\
\hline (a) & 4.585 & 0.000 & - \\
\hline X1) & -0.209 & 0.291 & $\begin{array}{c}\text { H1 } \\
\text { Ditolak }\end{array}$ \\
\hline (X2) & 0.049 & 0.815 & $\begin{array}{c}\text { H2 } \\
\text { Ditolak }\end{array}$ \\
\hline $\begin{array}{l}\text { F =0,475 } \\
\text { Adjusted R Square }=0,014\end{array}$ \\
\hline
\end{tabular}

Sumber: Olahan Data SPSS, 2017. 
Berdasarkan hasil analisis regresi linier berganda, berikut ini dapat dikemukakan persamaan regresi linier berganda:

$$
\mathrm{Y}=4,585-0,209 \mathrm{X}_{1}+0,049 \mathrm{X}_{2}
$$

Koefisisen regresi masing-masing

variabel penelitian dapat diartikan sebagai berikut:

1. Nilai konstanta sebesar 4,585 berarti tanpa adanya pengaruh dari variabel bebas maka nilai variabel terikat sebesar 4,585. Hal ini berarti bahwa apabila variabel bebas nilainya konstan (stress kerja dan motivasi kerja), maka nilai variabel prestasi kerja sebesar 4,585.

2. Besaran koefisien regresi variabel stress kerja bernilai negatif bermakna jika variabel stress kerja mengalami kenaikan maka prestasi kerja akan mengalami penurunan. Koefisien bernilai negatif artinya terjadi hubungan negatif antara stres kerja dengan prestasi kerja, semakin tinggi stress kerja maka prestasi kerja akan semakin rendah. Besaran koefisien regresi variabel stress kerja adalah $-0,209$ satuan. Hal ini bermakna bahwa jika terjadi peningkatan stress kerja sebesar satu satuan dengan asumsi variabel motivasi kerjatetap, maka akan menurunkan prestasi kerja sebesar - 0,209 satuan.

3. Besaran koefisien regresi variabel motivasi kerja bernilai positif bermakna jika variabel motivasi kerja mengalami kenaikan maka prestasi kerja akan mengalami peningkatan. Koefisien bernilai positif artinya terjadi hubungan positif antara motivasi kerja dengan prestasi kerja, semakin tinggi motivasi kerja maka prestasi kerja akan semakin tinggi. Besaran koefisien regresi variabel motivasi kerja adalah 0,049 satuan. Hal ini bermakna bahwa jika terjadi peningkatan motivasi kerja sebesar satu satuan dengan asumsi variabel stress kerjatetap, maka akan meningkatkan prestasi kerja sebesar 0,049 satuan.

Berdasarkan hasil pengolahan data terlihat bahwa variabel stress kerja memiliki nilai signifikansi sebesar 0,291 tahapan pengujian dilakukan dengan menggunakan tingkat kesalahan sebesar 5\% $(0,05)$, dengan demikian terlihat bahwa nilai signifikansi 0,291 lebih besar dari alpha 0,05, maka keputusannya adalah Ho di terima dan Ha ditolak. Jadi dapat disimpulkan bahwa stress kerja tidak berpengaruh terhadap prestasi kerja karyawan pada PT. Frisian Flag Indonesia Wilayah Padang.

Hipotesis kedua menunjukkan bahwa variabel motivasi kerja memiliki nilai signifikansi sebesar 0,815 tahapan pengujian dilakukan dengan menggunakan tingkat kesalahan sebesar 5\% $(0,05)$, dengan demikian terlihat bahwa nilai signifikansi 0,815 lebih besar dari alpha 0,05, maka keputusannya adalah Ho di terima dan Ha ditolak. Jadi dapat disimpulkan bahwa motivasi kerja tidak berpengaruh terhadap prestasi kerja karyawan pada PT. Frisian Flag Indonesia Wilayah Padang.

dari proses pengujian koefisien determinasi yang telah dilakukan diperoleh ringkasan hasil seperti yang terlihat pada Tabel 4.19, diketahui bahwa dari pengujian Koefisien Determinasi terlihat nilai koefisen determinasi adalah sebesar 0,014 atau sama dengan 1,4\%. Hasil tersebut memperlihatkan bahwa dari prestasi kerja karyawan yang dapat dijelaskan oleh stress kerja dan motivasi keerjasebesar $1,4 \%$, sedangkan sisanya $98,6 \%$ diduga dijelaskan oleh faktor-faktor lain yang tidak diteliti dalam penelitian ini, seperti disiplin kerja, budaya organisasi, iklim kerja, kepemimpinan, kompensasi, dan lingkungan kerja.

Berdasarkan hasil pengolahan data pada Tabel 4.16 terlihat bahwa variabel stress kerja memiliki nilai signifikansi sebesar 0,291 tahapan pengujian dilakukan dengan menggunakan tingkat kesalahan sebesar 5\% $(0,05)$, dengan demikian terlihat bahwa nilai signifikansi 0,291 lebih besar dari alpha 0,05, maka keputusannya adalah Ho di terima dan $\mathrm{Ha}$ ditolak. Jadi dapat disimpulkan bahwa stress kerja tidak berpengaruh terhadap prestasi kerja 
karyawan pada PT. Frisian Flag Indonesia Wilayah Padang.

Mangkunegara

(2008:179)

mengemukakan stres kerja sebagai suatu ketegangan atau tekanan yang dialami ketika tuntutan yang dihadapkan melebihi kekuatan yang ada pada diri kita. Sedangkan Handoko (2001:63) menyebutkan bahwa stres adalah tuntutan-tuntutan eksternal yang mengenai seseorang, misalnya obyek-obyek dalam lingkungan atau suatu stimulus yang secara obyektif adalah berbahaya. Stres juga biasa diartikan sebagai tekanan, ketegangan atau gangguan yang tidak menyenangkan yang berasal dari luar diri seseorang. Begitu pula menurut Hasibuan (2009) mengemukakan bahwa stres adalah suatu kondisi ketegangan yang mempe-ngaruhi emosi, proses berfikir dan kondisi seseorang.

Hasil penelitian ini tidak sejalan dengan hasil penelitian terdahulu yang dilakukan oleh Anisah Nurmalasari. (2015), dengan judul penelitian Pengaruh Stress Kerja Terhadap Prestasi Kerja Pegawai Di Kecamatan Malinau Kota Kabupaten Malinau. Adapun temuan dalam penelitian ini adalah pertama, stress kerja ternyata mempunyai pengaruh terhadap prestasi kerja pegawai pada kecamatan malinau kota kabupaten malinau. Kedua, besarnya pengaruh stress kerja terhadap prestasi kerja di Kecamatan Malinau Kota Kabupaten Malinau adalah sebesar 39,80\%.

Penelitian lain yang dilakukan oleh Endang Suswati dan Ibnu Azizi Al Ayyubi (2008), dengan judul penelitian Pengaruh Stress Kerja Terhadap Prestasi Kerja Karyawan.. Terdapat pengaruh yang signifikan secara simultan dari stress kerja yang meliputi stress fisiologis, stress psikologis dan stress perilaku terhadap prestasi kerja karyawan bagian produksi pada perusahaan pengalengan ikan PT. Indohama Fish Bali.

Penelitian Inke Okta Putri Wulandari, dkk. (2015) dengan judul Pengaruh Stres Kerja Dan Lingkungan Kerja Terhadap Prestasi Kerja (Studi Pada Karyawan Bagian Pabrikasi Pg. Kebon Agung Malang).Hasil $\mathrm{t}$ test antara variabel stress kerja dengan variabel prestasi kerja berpengaruh signifikan, yang berarti prestasi kerja dapat dipengaruhi oleh stress kerja, hal ini didapat dari $\mathrm{t}$ hitung $=4,057>\mathrm{t}$ tabel $=2,005$, dan hasil dari $\mathrm{t}$ test antara variabel lingkungan kerja dengan variabel prestasi kerja menunjukkan $\mathrm{t}$ hitung $=2,973>\mathrm{t}$ tabel $=2,005$, sehingga dapat disimpulkan bahwa prestasi kerja dapat dipengaruhi secara signifikan oleh lingkungan kerja.

Hipotesis kedua menunjukkan bahwa variabel motivasi kerja memiliki nilai signifikansi sebesar 0,815 tahapan pengujian dilakukan dengan menggunakan tingkat kesalahan sebesar 5\% (0,05), dengan demikian terlihat bahwa nilai signifikansi 0,815 lebih besar dari alpha 0,05, maka keputusannya adalah Ho di terima dan Ha ditolak. Jadi dapat disimpulkan bahwa motivasi kerja tidak berpengaruh terhadap prestasi kerja karyawan pada PT. Frisian Flag Indonesia Wilayah Padang.

Faktoryang mempengaruhi prestasi kerja seseorang menurut Mangkunegara (2009: 6768) adalah motivasi. Motivasi terbentuk dari sikap (attitude) seorang pegawai dalam menghadapi situasi (situation) kerja. Motivasi merupakan kondisi yang menggerakan diri pegawai yang terarah untuk mencapai tujuan organisasi (tujuan kerja). Sikap mental merupakan kondisi yang mendorong diri pegawai untuk berusaha mencapai prestasi kerja secara maksimal. Sikap mental seorang pegawai harus siap secara psikofisik (siap mental, fisik, tujuan dan situasi). Artinya, seorang pegawai harus mampu secara mental, mampu secara fisik, memahami tujuan utama, dan target kerja yang akan dicapai serta mampu memanfaatkan dan menciptakan situasi kerja.

Hasil penelitian ini tidak sejalan dengan hasil penelitian terdahulu yang dilakukan oleh Achmad Rusyad Manfaluti, dkk. (2016) dengan judul penelitian Pengaruh Motivasi Dan Kompensasi Terhadap Prestasi Kerja Karyawan Perusahaan Daerah Air Minum Kota Mojokerto.Berdasarkan t uji yang telah dibahas pada bagian sebelumnya jelas bahwa seluruh variabel independent yang terdiri motivasi dan kompensasi secara parsial berpengaruh 
signifikan terhadap prestasi kerja karyawan perusahaan daerah air minum Kota Mojokerto.

Penelitian lain yang dilakukan oleh Bonar P. Silalahi (2014) dengan judul Pengaruh Motivasi, Pengawasan Dan Disiplin Kerja Terhadap Prestasi Kerja Pegawai Dinas Pendapatan, Pengelola Keuangan Dan Kekayaan Daerah Kabupaten Tapanuli Tengah.Hasil uji pada alpha $5 \%$ menunjukkan bahwa motivasi, pengawasan dan disiplin kerja berpengaruh positif dan signifikan terhadap prestasi kerja, hal ini menunjukkan bahwa semakin tinggi tingkat motivasi, pengawasan dan disiplin kerja yang diberikan akan dapat meninbulkan prestasi kerja yang tinggi.

\section{PENUTUP}

\section{Kesimpulan}

Bedasarkan hasil penelitian dan pembahasan maka dapat disampaikan beberapa kesimpulan penelitian sebagai berikut:

1. Stress kerja tidak berpengaruh terhadap prestasi kerja karyawan PT. Frisian Flag Indonesia Wilayah Padang.

2. Motivasi kerja tidak berpengaruh terhadap prestasi kerja karyawan PT. Frisian Flag Indonesia Wilayah Padang.

3. Dari hasil olahan data, diketahui bahwa dari pengujian Koefisien Determinasi sebesar 0,014 atau sama dengan $1,4 \%$. Hasil tersebut memperlihatkan bahwa dari prestasi kerja karyawan yang dapat dijelaskan oleh stress kerja dan motivasi keerjasebesar 1,4\%, sedangkan sisanya $98,6 \%$ diduga dijelaskan oleh faktor-faktor lain yang tidak diteliti dalam penelitian ini, seperti disiplin kerja, budaya organisasi, iklim kerja, kepemimpinan, kompensasi, dan lingkungan kerja.

4. Dari analisis regresi linier berganda, ditemukan bahwa stress kerja berpengaruh negatif terhadap prestasi kerja dan motivasi kerjaberpengaruh positif terhadap prestasi kerja karyawan PT. Frisian Flag Indonesia Wilayah Padang.

\section{Keterbatasan dan Saran Penelitian}

Peneliti menyadari bahwa penelitian yang telah berhasil dilaksanakan ini masih memiliki beberapa kekurangan yang disebabkan adanya keterbatasan yang peneliti miliki selama pembuatan skripsi ini. Keterbatasan tersebut meliputi:

1. Penelitian ini hanya melihat pengaruh faktor stress kerja dan motivasi kerja terhadap prestasi kerja karyawan pada PT. Frisian Flag Indonesia Wilayah Padang. Disarankan untuk peneliti selanjutnya menambahkan variabel lain dalam penelitian ini.

2. Pengambilan data primer hanya melalui kuesioner. Pengumpulan data melalui kuesioner mempunyai kelemahan, yaitu perbedaan pandangan responden terhadap sesuatu. Sehingga dalam penelitian ini peneliti tidak dapat mengendalikan jawaban responden. Peneliti selanjutnya diharapkan dapat mengumpulkan data primer melalui kuesioner dan wawancara agar hasil lebih sempurna.

\section{DAFTAR PUSTAKA}

Achmad Rusyad Manfaluti, dkk. 2016. Pengaruh Motivasi Dan Kompensasi Terhadap Prestasi Kerja Karyawan Perusahaan Daerah Air Minum Kota Mojokerto. Ji_Mild - Volume Vii Nomor 1 - Agustus 2016 Issn: 2337$697 x$

Anisah Nurmalasari. 2015. Pengaruh Stress Kerja Terhadap Prestasi Kerja Pegawai Di Kecamatan Malinau Kota Kabupaten Malinau. Ejournal Pemerintahan Integratif, 2015,1(3); 102-114 Issn 2337-8670

Anoraga, Panji. 2009. Psikologi Kerja, Jakarta : Rineka Cipta

Arikunto, S. 2010. Prosedur penelitian : Suatu Pendekatan Praktik. (Edisi. Revisi). Jakarta : Rineka Cipta

Bohlander and Snell. 2010. Principle of Human Resource Management. Canada: Nelson Education, Ltd. 
Danim, Sudarman. 2001. Motivasi Kepemimpinan dan Efektivitas Kelompok. Penerbit Rineka Cipta.

Dessler. Garry. 2010. Manajemen Sumber Daya Manusia. Jakarta. Indeks.

Endang Suswati dan Ibnu Azizi Al Ayyubi. 2008. Pengaruh Stress Kerja Terhadap Prestasi Kerja Karyawan. Jurnal Manajemen Gajayana Vol. 5, No. 2, November 2008, 119---128 E.

Fitria Damayanti. 2014. Pengaruh Lingkungan Kerja Dan Motivasi Terhadap Prestasi Kerjadi Smp Negeri 1 Widasari Kabupaten Indramayu. Issn 1693-7945 Vol. Vi, No. 12, Nov 2014.

Gede Ari Setiawan. 2016. Pengaruh Motivasi Kerja Dan Kompensasi Terhadap Prestasi Kerja Karyawan PT. Sun Star Motor Cabang Negara Tahun 2016. Jurnal Program Studi Pendidikan Ekonomi Vol: 8 Nomor: 3 Tahun 2016.

Handoko, T. Hani .2011. Manajemen Personalia Sumberdaya Manusia, BPFE, Yogyakarta

.2001. Manajemen Personalia dan Sumberdaya Manusia,Edisi. Kedua. BPFE, Yogyakarta

Hasibuan, Malayu. 2013. Manajemen Sumber Daya Manusia:Pengertian Dasar, Pengertian, dan Masalah. Jakarta: PT. Toko Gunung Agung. 2009. Manajemen: Dasar, Pengertian, dan Masalah. Edisi Revisi. Jakarta : Bumi Aksara.

2007. Manajemen Sumber Daya Manusia. Jakarta : Cetakan 9. PT. Bumi Aksara.
2004. Manajemen Sumber Daya Manusia. Cetakan ke Tujuh, edisi revisi, PT. Bumi Aksara. Jakarta.

Inke Okta Putri Wulandari, dkk. 2015. Pengaruh Stres Kerja Dan Lingkungan Kerja Terhadap Prestasi Kerja (Studi Pada Karyawan Bagian Pabrikasi Pg. Kebon Agung Malang). Jurnal Administrasi Bisnis (Jab)| Vol. 1 No. 1 Januari 2015 Administrasi Bisnis.Studentjournal.Ub.Ac.Id

Ishak, Arep. 2003. Manajemen Motivasi. Jakarta: PT. Grasindo.

Jouita Victoria Pattynama, dkk. 2016. Pengaruh Motivasi Kerja, Disiplin Kerja, Dan Kepemimpinan Terhadap Prestasi Kerja Pegawai Di Badan Perpustakaan Provinsi Sulawesi Utara. Issn 23031174 J.V. Pattynama., Ch. Kojo., A.L. Repi. Pengaruh Motivasi Kerja... 514 Jurnal Emba Vol.4 No.1 Maret 2016, Hal. 514-523.

Kadarisman, M. 2013. Manajemen Pengembangan Sumber Daya Manusia. Penerbit:PT. Raja Grafindo Persada. Jakarta

Luthans, Fred. 2006. Perilaku organisasi. Edisi 10. Yogyakarta : Andi

Mangkunegara, A.A. Anwar Prabu. 2013. Manajemen Sumber Daya Manusia Perusahaan. Bandung:PT.Remaja Rosdakarya.

, 2008 Manajemen Sumber Daya Manusia,. Cetakan kelima, Penerbit PT. Remaja Rosdakarya. Bandung

2002. Manajemen Sumber Daya Manusia. Perusahaan. Bandung: PT. Remaja Rosdakarya. 
Martoyo, Susilo. 2007, Manajemen Sumber Daya Manusia, Edisi 5, Cetakan Pertama,. BPFE Yogyakarta

Mas'ud, Fuad. 2004. Survai Diagnosis Organisasional Konsep \& Aplikasi. Badan Penerbit Universitas Diponegoro. Semarang.

Mathis, Robert L. dan John H. Jackson. 2012. Manajemen Sumber Daya Manusia, Salemba Empat, Jakarta.

Mondy, R. Wayne, 2010, Human Resource Management Eleventh Edition. New. Jersey: Prentice Hall.

Munandar, A.S. 2008, Psikologi Industri dan Organisasi, Universitas Indonesia, Jakarta.

Nasution, Mulia, 2000. Manajemen Personalia Aplikasi Dalam. Perusahaan, Djambatan, Jakarta.

Nurlia Karim. 2013. Stres Kerja Pengaruhnya Terhadap Prestasi Kerja Pada Karyawan Café Bambu Express Manado. Issn 2303-1174 Henry G. Piri, Kualitas Pelayanan Jasa Pengaruhnya... Jurnal Emba 513 Vol.1 No.4 Desember 2013, Hal. 513522.

Rivai, Veithzal, 2006. Manajemen Sumber Daya Manusia untuk Perusahaan: dari Teori Ke Praktik, Edisi Pertama, Penerbit PT. Raja Grafindo Persada, Jakarta.

. 2004. Manajemen Sumber Daya Manusia Untuk Perusahaan : Dari Teori Ke Praktik. PT. Raja Grafindo Persada, Jakarta.

Robbins, Stephen P. 2001. Perilaku Organisasi: Konsep, Kontroversi, Aplikasi, Jilid. 1, Edisi 8, Prenhallindo, Jakarta.
Sekaran, Uma. 2006. Research Methods For Business, Edisi Keempat. Salemba Empat: Jakarta

Siagian, Sondang,2007, Manajemen Sumber Daya Manusia, Jakarta : PT. Bumi Aksara.

Sihotang, A. 2007. Manajemen Sumber Daya Manusia. Jakarta : Pradnya.

Sugiyono. 2013. Metode Penelitian Manajemen, Cetakan Pertama, Alfabeta:Bandung

Sunyoto, D. 2015. Manajemen dan Pengembangan Sumber Daya Manusia. Penerbit:CAPS, Yogyakarta

Sunyoto, Suyanto.2011. Analisis Regresi dan Uji Hipotesis. Yogyakarta: Caps

Sutrisno, Edy. 2011. Manajemen Sumber Daya Manusia. Jakarta: Kencana

Umar, Husein. 2013.Metode Penelitian Untuk Skripsi dan Tesis Bisnis. PT. Raja Grafindo: Jakarta

Wayan Widiartana. 2016. Pengaruh Gaya Kepemimpinan Dan Motivasi Kerjaterhadap Prestasi Kerja Karyawan Pada Ud. Sinar Abadi. Jurnal Program Studi Pendidikan Ekonomi Vol: 6 Nomor: 1 Tahun 2016. 